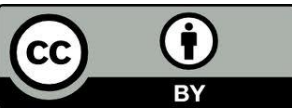

\title{
RELIGIÃO E POLÍTICA SEGUNDO MARCEL GAUCHET
}

\author{
Religion and politics according Marcel Gauchet
}

Elio Roberto Pinto Santiago Filho

Doutorando em Ciência da Religião

Universidade Federal de Juiz de Fora

eliosantiagojf@gmail.com

Resumo: Este artigo objetiva analisar a relação entre religião e política segundo o pensamento de Marcel Gauchet, expondo em linhas gerais sua tese sobre as metamorfoses políticas da religião ao longo da história. O texto procura mostrar como as principais revoluções da história estariam ligadas a mudanças radicais no fundamento do ser-conjunto, inserindo uma interpretação alternativa ao diagnóstico laico e secular das sociedades modernas.

Palavras-chave: Religião; política; modernidade; Marcel Gauchet.

Abstract: This article aims to analyze the relationship between religion and politics according to Marcel Gauchet's thought, exposing in general lines his thesis about the political metamorphoses of religion throughout history. This paper seeks to show how the major revolutions in history are linked to radical changes in the ground of being-together, entering an alternative interpretation to the lay and secular diagnosis of modern societies.

Key words: Religion; politics; modernity; Marcel Gauchet. 


\section{Introdução}

As sociedades ocidentais modernas têm sido observadas e caracterizadas como sociedades com alto nível de secularização, em que a política teria abandonado de vez a religião e o indivíduo encontrado sua emancipação final. A autonomia humana teria, nessa ótica, substituído radicalmente a heteronomia enquanto ordem ontológica, permitindo que as decisões políticas não dependessem mais de um Outro ou do transcendente.

Mas esse diagnóstico da modernidade teria raízes fundamentalmente religiosas. As principais revoluções da história teriam uma herança sagrada que evidencia sucessivas metamorfoses do Religioso, enquanto fundamento do social. O objetivo desse artigo é expor, em linhas gerais, o pensamento do filósofo e historiador francês Marcel Gauchet ${ }^{1}$ sobre a dívida religiosa da política, mostrando uma interpretação alternativa ao laicismo ocidental e ao desencantamento do mundo. Para tanto, parte-se de um diálogo do autor com o pensamento do antropólogo Pierre Clastres, do qual Gauchet retira seu problema inicial a partir das sociedades sem Estado estudadas por ele na América Latina. Em seguida, o texto apresenta a teoria de Gauchet sobre as metamorfoses do religioso ao longo da história, traçando seus arranjos principais e sua dimensão política.

\section{A fusão cosmo-biológica e as sociedades sem Estado}

Como um parâmetro analítico para a obra de Gauchet, o problema levantado por Clastres (1982) no que se refere a uma sociedade acephalous, ou seja, uma sociedade sem poder centralizado, sempre foi emblemático para a antropologia. Seja por não dar uma medida de onde poderia se dar a organização social, seja por ser tão estranha aos moldes da interpretação política, a questão afigurou-se como de grande interesse por inferir em uma existência alternativa de gestão do todo social. Como

\footnotetext{
1 Marcel Gauchet é um filósofo e historiador francês que tem se dedicado nas últimas décadas ao estudo da política moderna, bem como sua interface com a religião. É autor de diversos livros e artigos sobre a gênese social do ocidente a partir dos seus principais problemas políticos. Atualmente é diretor de estudos na L'École des Hautes Études en Sciences Sociales. O presente artigo toma como referência apenas uma parte da sua obra em que já é possível, em linhas gerais, visualizar as preocupações que o ocupam em sua trajetória intelectual.
} 
exemplo, o antropólogo Evans-Pritchard (1993) já se interrogava sobre o que seria exatamente a esfera política entre os Nuer, uma sociedade tribal acephalous que se dispersa ao longo do rio Nilo no Sudão, onde a alta segmentação social baseada no parentesco determinava uma dispersão espacial e temporal ${ }^{2}$ que não permitia a visualização de nenhuma centralização do poder. Chega ao ponto de mencionar a existência de uma anarquia democrática, visto que ninguém dessa sociedade conseguia tomar a ponta de uma hierarquia política. De modo comparado às sociedades sulamericanas estudadas por Clastres, entre os Nuer existe um chefe, mas sem poder de determinação comportamental, sendo apenas um mediador de conflitos. Ele é chamado de chefe da pele de leopardo e age somente como o mediador de alguns problemas, não podendo ditar nenhuma ordem, pois apenas apazígua conflitos específicos. Os chefes tribais ameríndios estudados por Clastres também não exercem poder algum; são apenas portadores do discurso mítico, agindo como guardiões da memória tribal.

Cabe ressaltar que o papel do chefe nessas sociedades tão distantes simbolicamente das nossas apresenta outra dimensão do fato. Paradoxalmente, suas existências servem para confirmar a não possibilidade da ação de um poder centralizador. Assim, há um chefe despossuído de poder para demonstrar que a igualdade social está baseada no fundamento da Tradição. Qual seria então o eixo da organização social nessas sociedades, e no caso daquelas estudadas por Clastres, em torno do que elas se estruturam?

No imaginário ocidental, a não existência de um poder centralizador aparece como uma falta, sendo vista como exótica e como exemplo de primitivismo (GAUCHET, 2005, p. 92; CLASTRES, 1982, p. 133). Segundo Clastres, a própria teoria etnológica oscila entre duas ideias opostas e complementares: "Tudo se passa então como se as sociedades primitivas estivessem colocadas diante de uma alternativa: ou a falta da instituição e o seu horizonte anárquico, ou o excesso dessa mesma instituição e o seu destino despótico" (CLASTRES, 1982, p. 21).

Para Gauchet, a análise de Clastres serve para demonstrar como as sociedades sem escrita se organizam. O que Gauchet denomina de "ato sociológico" faz referência

\footnotetext{
2 Ressalta-se que os Nuer organizam suas linhagens agnaticamente, traçando as descendências até um ancestral homem que seja comum. Daí que Evans-Pritchard mostra como estas linhagens estão organizadas no tempo através de um ancestral comum dentro dos diversos segmentos; e no espaço através da dispersão territorial e de seus deslocamentos.
} 
à decisão da sociedade quanto ao seu desdobramento em vista do poder, da história e da sua relação com a natureza, e permite que sejam colocadas em evidência as concepções relativas às formações sociais existentes.

Com efeito, nas sociedades sem poder centralizador é comum que um sistema de parentesco rígido substitua a função do Estado de estruturar a organização social. Tal fato é caracterizado pelos Nuer, que organizam a sociedade pela linguagem do parentesco no seu rígido sistema de linhagens. Gauchet reitera que, mesmo quando existem essas diferenciações dadas pelas linhagens, clãs, classes de idade ou grupos familiares, não há uma assimetria radical como aquela que separa governados e governantes, o que ocorre quando há Estado (GAUCHET, 2005, p. 21). A manifestação dessas formas de organização social não infere na existência de uma distância entre os indivíduos, e muito menos permite a determinação do comportamento do outro como uma manifestação de poder.

Ressalta-se que nessas sociedades havia a diferença, mas não havia mecanismos para absorvê-las no seio do social. O conflito estava resolvido a priori com as razões instauradoras do social atribuídas a um Outro. Para Gauchet, o que vemos é uma fusão cosmo-biológica; mito e realidade se equivaliam, onde natureza e tornam-se são indivisíveis; pessoas e animais fazem parte da mesma humanidade. A religião está no centro do princípio organizador e estruturador do social. Daí a dificuldade de separar esses dois termos, pois na sociedade primitiva estão interligados como somente uma coisa. É nessa "cosmo-fusão" onde, de acordo com Gauchet, encontramos a religião mais sistemática e completa (Ibid., p. 35).

A designação desse modelo primitivo como apresentando uma completude ontológica nos remete à explicação de Clastres, a sua advertência ao modo de como a antropologia política observava esses grupos. Por verem as sociedades primitivas acéfalas como incompletas, os antropólogos logo projetavam a noção ideal de sociedade que tinham em vista. Concebiam-nas como à margem da história, em substantiva anacronia com o devir determinado de toda organização social. Clastres ainda complementa, afirmando que o velho evolucionismo permanece intacto por trás das formulações modernas (CLASTRES, 1982, p. 133). Ora, a história da antropologia é enfática ao esclarecer a superação da perspectiva evolucionista. O projeto de se encontrar uma linha única do desenvolvimento social foi há muito derrubada pelo 
relativismo cultural. E não somente a falta de Estado, mas também a noção de trabalho das sociedades ocidentais civilizadas é tida como parâmetro para comparar as sociedades primitivas. Sendo assim, destarte, os grupos ameríndios primitivos tem sido percebidos como dotados de uma economia de subsistência, sem técnica aperfeiçoada e vivendo refém de suas necessidades. Escreve Clastres sobre esse diagnóstico:

Dois axiomas, com efeito, parecem guiar a marcha da civilização ocidental, desde a sua aurora: o primeiro estabelece que a verdadeira sociedade se desenvolve sob a sombra protetora do Estado; o segundo enuncia um imperativo categórico: é necessário trabalhar (Ibid., p. $135)$.

As sociedades primitivas, por recusarem a produção de excedentes e o trabalho desnecessário que ultrapasse as necessidades imediatas, negam a economia como um campo autônomo. Pode-se falar em trabalho, segundo Clastres, apenas quando a produção tribal é destituída do valor da reciprocidade e quando a regra igualitária da troca não é mais o "código civil” compartilhado (Ibid., p. 138). Mas a reciprocidade tem um papel muito mais amplo. Segundo Gauchet, a regra da reciprocidade determina uma anterioridade em relação à vontade dos indivíduos postos em relação. Assim sendo:

A lei da reciprocidade é, tanto na paz do intercambio consentido como no desencadeamento que restitui a vingança, o inquestionavelmente religioso do fundamento formado de relação social; é o prevalecer unânime, assegurado em ato, das razões últimas contra o que compromete uns indivíduos com relação a outros, livre deliberação ou mortal oposição ${ }^{3}$ (GAUCHET, 2005, p. 42).

A economia do vínculo social das sociedades primitivas está relacionada com a despossessão radical e com a alteridade total do fundamento. A Lei, cabe ressaltar, não está ao alcance dos sujeitos, mas em um passado fundador. As obrigações práticas do cotidiano dos "presentes vivos" não procedem de uma decisão autônoma, mas correspondem a uma ordem já a priori definida e reafirmada pelo rito como alteridade

\footnotetext{
3 No original: "La ley de la reciprocidad es, tanto em la paz del intercambio consentido como em el desencadenamiento que restituye la venganza, lo incuestionablemente religioso del fundamento formado de relación social; es el prevalecer unánime, asegurado em acto, de las razones últimas contra lo que compromete a unos indivíduos com outros, libre deliberación o mortal oposición”
} 
sagrada. A realidade como dada em um tempo mítico retira o movimento e a história da economia do vínculo social. Se, como afirma Gauchet (Ibid., p. 37), só existem sociedades dentro da história, que a repetição pura é impossível ao homem, por que então a negação do movimento? A despossessão radical exprime a inexistência de autogestão do social e a fidelidade total ao passado fundador dado como verdade irrefutável e imanente.

Uma relação se torna determinante. O passado mítico por mais distante que esteja como momento inaugural, está presente no espaço e na prática do presente. É essa correlação entre presença e distância que determina a relação da religião com a sociedade e do seu papel axiomático no vínculo social. A despossessão radical torna-se doravante política. A distância em relação ao passado instaurador não permite que se fale em nome da norma sagrada, instituindo um monopólio representativo do divino. Uma sociedade de iguais, organizada por uma norma intangível, não permite a superioridade de nenhum de seus indivíduos. Este ato sociológico objetiva conjurar a dominação política, ejetá-la das possibilidades do convívio social. O papel do chefe nessas sociedades não está relacionado ao poder de mando, e não estando hierarquicamente acima dos outros. Como já dito, ele sustenta um papel discursivo, de portador da história mítica, cabendo transmiti-la para o resto da sociedade.

A inclusão cosmo-biológica pode ser definida, em termos gerais, como a fundição do indivíduo com a natureza. Questão antropológica fundamental no que tange à relação entre natureza e cultura. Para Gauchet, a fusão cosmo-biológica diz respeito a

Uma integração carnal nos ciclos do céu, (...) neutralização de fato do antagonismo potencial alojado na relação do homem com a natureza, mediante a substituição de uma postura constituinte de confrontação por uma postura simbólica de pertencimento (Ibid, p. 40) ${ }^{4}$.

Cabe ressaltar que as religiões primitivas apresentam uma natureza difusa e complexa. Gauchet considera o politeísmo e a magia coexistindo no âmago do convívio social um "formigueiro de causas ocultas". A principal característica cognitiva dessa complexidade religiosa, expressa-se quando a realidade está fundida no mito em uma

\footnotetext{
$4 \quad$ No original: “(...) como integración em los ciclos del cielo, (...) neutralización de facto del antagonismo potencial alojado em la relación del hombre com la naturaleza, mediante la sustitución de una postura constituyente de confrontación por una postura simbólica de pertenencia."
} 
junção espacial e temporal. Não há separação entre sujeito e objeto, marcando um ponto nebuloso de compreensão do "pensamento selvagem".

Nas sociedades primitivas, onde, de acordo com Gauchet, encontrava-se a religião mais sistemática e completa, neutraliza-se o antagonismo radical, transferindo as razões instauradoras do social a outro lugar fora do alcance dos viventes. É esta superioridade e anterioridade da ordem que coloca a vontade dos indivíduos como limitada. Isso não significa que não existem conflitos nessas sociedades, mas ele é ejetado, resolvido como não sendo constitutivo do social.

\section{O surgimento do Estado}

Uma pergunta simples de Clastres inverte a natureza das sociedades sem Estado: qual necessidade cumpre o Estado? Se nas sociedades primitivas existe uma negação da economia como produção de excedentes, se não há divisão de classes antagônicas e se a palavra do chefe não tem força de lei, cabe questionarmos qual seria o papel do Estado e sua condição. Já que nessas sociedades não há espaço para o poder político isolado, não há uma lacuna a ser preenchida pelo Estado. A interdição da autonomia, como afirma Clastres (1982, p. 147), tem por objetivo manter a direção da sociedade pela sociedade e não por meio do indivíduo, mas pelo coletivo. A função da sociedade é a reprodução, a imobilidade e a negação do movimento.

Há dessa forma uma não necessidade do Estado nessas sociedades e, ademais, há uma negação de sua possibilidade. Mas Clastres insere uma questão substancial para compreender a condição do seu surgimento. Seria o problema demográfico, em que o modelo de sociedade primitiva acéfala só pode funcionar quando há um pequeno contingente populacional. Soma-se a isso o papel das prédicas proféticas sustentadas pelos tupi-guaranis nos séculos XV e XVI que apelavam para o abandono da terra má para alcançar a Terra sem Mal. Como afirma Clastres:

Habituados pelo sentimento de que o antigo mundo selvagem tremia em seu fundamento, perseguidos pelo pressentimento de uma catástrofe sócio-cósmica, os profetas decidiram que era preciso mudar o mundo, abandonar o dos homens e ganhar o dos deuses (Ibid., p. 150). 
Clastres interpreta esse sentimento de temor e de incerteza como reflexos da recusa do Estado, da assimilação do social em um corpo único. A palavra surge como reposta a um evento de difícil volta; o Estado ainda como mal virtual provoca na sociedade primitiva uma reação contrária a qualquer forma de imposição. Nesse contexto, destaca Clastres, já era possível observar os profetas realizando o programa dos chefes, conseguindo de uma forma ou de outra impor um poder. Este estava na palavra, e talvez, segundo o antropólogo, seria este o germe do poder.

Fatalismo sem precedentes, armadilha da história, fato é que o surgimento Estado determina para Gauchet a primeira revolução religiosa. Essa fratura no ser, como ele a define, remodela uma relação dada a priori. Passa a existir a divisão social, e o Outro não se encontra mais na sua intangibilidade total, mas tem seu representante terreno - o rei sagrado. Esse evento marcante, que parte a história em dois, ou melhor, é a entrada na história, traz mudanças radicais na forma primitiva de organização social. Necessariamente, o surgimento do Estado não significa a passagem da imobilidade ao movimento, mas passa a determinar a possibilidade de uma nova assimilação dos eventos. O que se torna central neste momento é a existência de mecanismos que permitam a mudança, sendo o Estado um marco revolucionário do ser-conjunto. No momento em que passa a haver a dominação seja qual for, ou a divisão de classes, o sentido da existência coletiva entra em evidência.

Essa primeira forma de Estado que Gauchet exemplifica é aquela em que há uma figura de poder que rompe com a igualdade primitiva. Surgem os reis sagrados, duplamente homens e deuses, como visto, por exemplo, nas sociedades précolombianas $^{5}$. Nesta forma inaugural de divisão terrena, o Outro religioso passa a estar na esfera humana. Transformação ontológica que redefine as posições sociais através de novas relações com o além. Logo, o que antes era neutralizado, o antagonismo radical, passa a estar no seio da coletividade e, mais ainda, passa a ser dada como natural.

Quando Gauchet menciona a igualdade na sociedade primitiva, não faz referência à ideia do bom selvagem. Muitas vezes funcionando como parâmetro analítico, a noção de grupo primitivo inicial é um balizamento feito por estudos

\footnotetext{
5 Segundo Gauchet o cristianismo afigura-se como a religião da saída da religião ao ter um messias ao mesmo tempo homem e Deus, evidenciando um movimento na história de disjunção radical com o fundamento, materializado doravante na terra, permitindo aos indivíduos a possibilidade de intervir na história. Jesus seria para Gauchet, um “messias ao reverso" (Cf. GAUCHET, 2005, p. 169-177).
} 
etnográficos em sociedades distantes. A permanência no tempo de sociedades sem Estado foi constatada em diversas partes do globo nas mais diversas condições culturais de existência. Daí, que relacionar o passado primitivo com a ideia do selvagem romântico é, nesse caso, não somente errôneo, como equívoco. O próprio conceito de primitivo foi questionado pela antropologia como uma forma de etnocentrismo, ou seja, dizer que certo povo é primitivo era dado como sinônimo de atraso. Tal nomenclatura destaca-se como ambígua. Analiticamente serve como parâmetro de um modelo societário e ideologicamente como conceituação de atraso. A proposta de Clastres e de Gauchet se adapta do uso analítico do conceito de "homem primitivo" como forma de ponderar um tipo de vínculo social que se organiza sem poder centralizador. Destarte, a igualdade não é sinônimo de falta de conflito e muito menos representa uma característica de sociedade harmônica. Ela é o oposto da distinção social em termos de poder, é a sociedade sem o controle hierárquico de um ou de vários. Pressupõe a não possibilidade do poder incorporado em algum sujeito terrestre no que se refere à determinação impositiva do comportamento da alteridade.

No caldeirão de transformações ocorridas com o surgimento do Estado ainda existem continuidades substanciais a serem ressaltadas. A função a hierarquia instituída será exercer o papel que era anteriormente do rito. Ela aloca as pessoas em espaços definidos - trabalho anterior feito pelo processo ritual. A sociedade ainda é organizada religiosamente, porém não mais como no reino do passado puro. Esse caminho, de acordo com Gauchet, é um caminho sem volta. Uma vez desfeita a conjunção inicial entre a norma e o ser, um hiato tende a se substanciar, um abismo que mostra uma ruptura ontológica e determinante para o que confluirá na sociedade racional moderna.

A entrada na história pontua a absorção do movimento no seio do ser-conjunto. A revolução que Gauchet destaca surge como um divisor de águas inevitável. Alguns eventos do período neolítico não são suficientes para provocar a fratura no ser que o Estado determinará. Nas palavras de Clastres:

A verdadeira revolução, na proto-história da humanidade, não é a do neolítico, uma vez que ela pode muito bem deixar intacta a antiga organização social, mas a revolução política é essa aparição misteriosa, irreversível, mortal para as sociedades primitivas, o que conhecemos sob o nome de Estado. E se quiser conservar os conceitos marxistas de infra-estrutura e de superestrutura, então talvez seja 
necessário aceitar reconhecer que a infra-estrutura é o político e que a superestrutura é o econômico (Ibid., p. 141).

Clastres inverte radicalmente a teoria marxista. Gauchet da mesma forma define essa teoria como limitada para definir o evento de forma ampla. Não são as condições materiais de existência que definem a revolução advinda com o surgimento do Estado, mas o poder como uma forma de cisão da igualdade. A reflexão de Clastres sobre a natureza do poder abre um questionamento - como é comum na antropologia - que recai sobre as sociedades modernas ocidentais.

\section{A ejeção do Outro e a abertura democrática}

Clastres demonstrou a cisão ontológica da sociedade com o surgimento do Estado que Gauchet designa como uma fratura do ser. Essa primeira revolução religiosa da história humana foi decisiva para as transformações sucessivas da relação entre religião e política. Com a transcendência total do Outro, o aqui, o mundo terreno, passa a estar cada vez mais em mãos humanas. $\mathrm{O}$ abismo entre o além e o vivido hic et nunc impõe a possibilidade do movimento em detrimento da estática sociedade primitiva. Mudam-se as práticas, recondiciona-se a conciliação radical da fusão cosmobiológica.

O nascimento da teologia, da tentativa sistemática de explicação do Outro, contextualiza a distância cada vez maior entre os homens e além. A especulação do invisível e do visível é fruto do deslocamento entre esses dois referentes e delineiam as novas possibilidades de apreensão do sagrado. Ele não está mais em conjunção com o homem, como nas sociedades primitivas, mas precisa ser revelado, descortinado, por meio do intelecto e de sua sistematização.

O fundamento, que já era dado como axiomático na sociedade primitiva e não precisava ser refletido, passa a ser acessível no presente vivido. Se na sociedade primitiva o passado fundador era auto-evidente e imanente, com a dinâmica da transcendência ele tende passar pelo crivo humano. É nessa possibilidade de criação dos homens no aqui e agora, na abertura ao movimento, que Gauchet visualiza o centro da ruptura com a idade mítico-mágica, invertendo-se a relação entre divindade e mundo (GAUCHET, 2005, p. 76). 
Mas qual a consequência dessa disjunção radical provocada pela transcendência do divino expressivamente longe dos desígnios humanos? Segundo Gauchet:

Isso institui no homem o sujeito do conhecimento, autonomizando-o em relação à inteligência divina, (privando-o da intuição intelectual que o abria diretamente ao conhecimento de Deus) e, correlativamente, tirando-o do tecido hierarquizado dos seres e das coisas em que matinha esta comunicação com uma divindade presente no $\operatorname{ser}^{6}$ (Ibid., p. 77).

O judaísmo representaria o momento inicial da ejeção total de Deus; um Deus inacessível e imprevisível, totalmente outro, imanipulável por qualquer tipo de técnica, seria o exemplo típico dessa nova percepção histórica de metamorfose do religioso que segue até a reforma protestante com a ejeção teórica de Deus.

A autonomização do homem em relação ao divino coloca a própria crença religiosa em evidência. A relação com o mundo não se dá mais por analogia, contágio e oposição (pilares do pensamento mágico), mas pela divisão entre sujeito e objeto. Daí que a revolução das condições de conhecimento é caudatária de um processo religioso de expressão da transcendência. Em um primeiro momento parece paradoxal afirmar que à grandeza de Deus e à elaboração sistemática da crença corresponde a maior autonomia da razão humana. Ou que enquanto mais se conhece Deus, mais se tem uma intelecção do mundo. Mas se remontarmos ao argumento de Gauchet, observaremos que essa dinâmica conduz o homem à necessidade da compreensão de Deus e à diferenciação de Deus. Essas duas circunstâncias descrevem duas possibilidades: a primeira consuma a distância operante do divino e a necessidade da revelação, e a segunda determina uma revolução do pensar, em que a distância espacial em relação ao fundamento recoloca o homem diante do mundo, é preciso agora buscar as leis que obedecem as coisas, e não mais Deus nas coisas.

O homem como sujeito de conhecimento passa a ter maior independência em relação ao divino na medida em busca a intelecção do presente vivido na sua plenitude como peça central do conhecimento. O impacto político dessa transcendência de Deus é

\footnotetext{
$6 \quad$ No original: “(...) instituye en el hombre el sujeto del conocimiento, autonomizándolo em relación con la inteligencia divina (privándolo de la intuición intelectual que lo abría directamente al conocimiento en Dios) y, correlativamente, sacándolo del tejido jerarquizado de los seres y de las cosas en que lo mantenía esta comunicación con una divinidad presente en el ser."
} 
a abertura à possibilidade da gestão terrena pelos próprios homens. Para Gauchet (Ibid., p. 85): "a absoluta separação da divindade retira qualquer imposição sensível aos homens da vontade de cima, abolição do poder mediador, anulação da dependência expressa e direta deste mundo em relação ao além". A auto-suficiência do corpo político é fruto da divisão entre o visível e o invisível que deixa os homens como organizadores do presente. O Estado passa a recompor os homens em torno de si e, mesmo havendo um aspecto régio de autoridade, a disjunção radical entre os dois espaços - do reino do visível e do invisível - potencializa-se na proximidade prática do exercício em ato da soberania dos indivíduos.

Como um processo idiossincrático, esse movimento de soberania não obedecerá a um processo harmônico em que a subjetividade emerge vitoriosa em face da objetividade do Estado. Se por um lado, com a transcendência do Outro, o mundo vivido passa a estar nas mãos dos próprios homens, a religião não desaparece, mas se transforma. A metamorfose do religioso permite uma continuidade, em outros termos, da relação entre religião e política. Na primeira revolução religiosa com o surgimento do Estado, a divindade passa a estar materializada na terra sob a figura de um rei sagrado, mas com a dinâmica da transcendência o fundamento do Estado passa a estar no "aqui”, reconduzindo a organização do vínculo social para o presente vivido.

A diferenciação de Deus que se expressa em sua sistematização teológica evidencia uma disjunção radical que possibilita a expansão da racionalidade humana no que tange à intelecção do movimento independente das coisas. A separação entre sujeito e objeto, como foi dito, abre as possibilidades do conhecimento para além da mediação divina. Este mundo passa a ser passível de transformação e o movimento estabelece a entrada das sociedades na história. O renascimento e o iluminismo exemplificam essa mudança de mentalidade face ao Outro. A autonomia do sujeito faz-se sentir na ejeção do religioso e no uso da razão na apropriação do mundo objetivo, em constante desmistificação.

A ligação da racionalidade moderna como dependente de um movimento de transcendência religiosa coloca o eixo dessa relação em outros termos. A racionalidade, a liberdade e a individualidade são, de acordo com Gauchet (Ibid., p. 92), os novos representantes da articulação entre visível e invisível. Ressalta-se que essa relação determinará uma remodelação do ser-no-mundo, uma recomposição do 
espaço social sob o símbolo da autonomia. Será no princípio latente de soberania dos indivíduos, princípio este gestado pela própria religião em sua dinâmica sucessiva de materialização, transcendência e possibilidade de recomposição do espaço social pelos homens, que o Estado será remodelado pela democracia.

A Revolução Francesa, que segundo Gauchet é a revolta daquilo que a religião criou em face de si mesma, mostra o impacto radical do estabelecimento da autonomia. Esse fato levará ao elaborado laicismo francês na sua insistente negação da religião como princípio de gestão do corpo político e social. Esse caso específico revela a profundidade moderna da relação entre religião e política. As suas consequências serão sentidas durante os séculos subsequentes o que modelará substancialmente o papel da religião e do Estado enquanto em oposição e co-constitutividade.

O laboratório francês será para Gauchet o ponto de partida para a observação das particularidades dessa relação, e a análise dos seus desdobramentos se torna essencial para a compreensão de dois fenômenos modernos denominados de secularização e laicismo, que Gauchet procurará reinterpretar e mostrar como a ponta de um iceberg de um evento ontológico. É preciso ligá-lo ao problema original da relação do político com o religioso, da relação entre a heteronomia e autonomia, entre o movimento e a negação da história. A soberania do corpo político seguirá desta forma uma trajetória no tempo pari passu com as reformulações religiosas, e erguerá a bandeira do indivíduo como vitorioso de uma luta que na verdade se deu por dentro da própria religião.

\section{Uma reinterpretação do laicismo francês}

A Revolução Francesa, como uma das mais importantes revoluções políticas do ocidente, foi uma afirmação da liberdade e da igualdade da população, deflagrada anteriormente por uma velha ordem despótica baseada em privilégios arbitrários. Na sociedade do Antigo Regime, estruturada aristocraticamente, onde o clero e a nobreza desfrutaram de privilégios especiais, havia uma estratificação legítima que dividia a população de forma semelhante à estrutura semifeudal. $\mathrm{O}$ catolicismo francês era a religião oficializada, o centro da moral social francesa. 
Com a crise financeira instalada na França na segunda metade do século XVIII, e com uma burguesia inconformada com sua condição subalterna, os primeiros vestígios de uma crise evoluíram em uma grande revolta. A fase radical da revolução, ao abolir a monarquia e decretar a república, instaurou uma nova ordem política baseada na soberania do povo. O significado desse processo foi a possibilidade de exercer a mudança de algo dado como evidente, ou seja, de provocar uma ruptura com uma ordem monárquica e aristocrática circunscrita como legítima. Nascia o Estado moderno na afirmação de soberania da nação e de governo do povo. A potencialidade da autonomia substanciava uma nova concepção de Estado. O espírito da revolução mostrou que a influência iluminista tinha encontrado espaço na concretude política.

Esse evento marcante na sociedade francesa demonstra um exemplo substancial de reordenamento político que ocorre no deslocamento das fontes de poder e do fundamento do Estado. Se no Antigo Regime o rei era o Estado, sacralizado religiosamente em sua posição, a soberania do povo não apenas evidenciou uma luta política, mas também religiosa. Segundo Gauchet (2003, p. 41), o laicismo francês pode ser divido em duas partes: a primeira vai do fim das guerras religiosas até a Revolução Francesa, ou até a constituição civil do clero em 1791; e a segunda vai do concordato napoleônico até 1975 - ano de grande crise econômica. Mas, segundo Gauchet, é necessário precisar os limites das expressões laicismo e secularização. Para o autor, esses termos são conjecturais, pois o que está em questão é "uma recomposição do conjunto humano por reabsorção, reforma e reelaboração daquilo que, durante milênios teve o rosto de alteridade religiosa" (Ibid., p. 24).

Soma-se ao diagnóstico moderno dado por Gauchet sobre os movimentos de secularização e privatização do religioso (Ibid., p. 25). No curso de uma sociedade em mudança, como na França do século XVIII, esses dois fenômenos tendem a se consolidar com o surgimento da sociedade civil. Nas palavras de Habermas (HABERMAS, 1984, p.24):

São bastante conhecidas as grandes tendências que se impôs até o final do século XVIII. Os poderes feudais, Igreja, realeza e nobreza dos quais dependem diretamente a representatividade pública decompõem-se ao longo do processo de polarização; por fim, cindemse em, de um lado, elementos privados e, de outro, em elementos públicos. A posição da Igreja modifica-se com a Reforma. A ligação que ela representa com a autoridade divina, re-ligião, torna-se coisa 
privada. A assim chamada liberdade de crença assegura historicamente a primeira esfera da autonomia privada; a própria Igreja continua a existir como uma corporação de Direito Público entre outras.

$\mathrm{Na}$ instauração da república francesa, a religião privatiza-se. Ela não está mais no domínio público em associação com o Estado. Na segunda fase do laicismo que Gauchet (2003, p. 50) chamará de fase liberal e republicana, haverá a separação definitiva entre Estado e religião. Nesse momento os resquícios do direito divino não possuem mais o poder de religar a religião com a figura do corpo político. Entra em cena a sociedade civil, que antes estava associada ao próprio Estado, e onde a religião será alocada.

A co-constitutividade do laicismo com a religião é representada pelo jogo de forças que é orquestrado na sociedade da época. A religião tentando sua repatriação e o laicismo procurando a autonomia do corpo político com o advento da república determinam uma relação de oposição que estabelece o vigor do afã laico. Essa transferência da religião para a sociedade civil não significa, entretanto, a perda da sua função. Passando da res pública para a esfera privada, passa a estar no domínio das consciências individuais. Porém, segundo Gauchet (Ibid., p. 56), a Revolução Francesa, que foi a "retomada do absoluto do poder em nome da nova legitimidade da nação" está ligada à metamorfose do religioso - como substrato antropológico. Daí a limitação conceitual que Gauchet dá aos termos laicismo e secularização por não darem conta do problema ontológico que está em questão. O religioso não desaparece, mas se transforma, metamorfoseia-se em outras figuras, em outras relações, moldando-se, adiante, no contexto da religião civil do Estado.

A primazia do Estado continuava como imperativa na França pós-revolução. Para Gauchet esse fato demonstra uma herança do absolutismo ao colocar o centro da sociedade no corpo político. Somente em seguida com o surgimento da sociedade civil, haverá um espaço de manifestação do corpo social desprendida da figura do Estado. Nessa ótica, podemos observar que o laicismo francês foi acompanhado de continuidades e rupturas em relação ao Antigo Regime. Frisa-se a metamorfose do religioso, o papel do Uno sendo atribuído ao Estado e a sua subsequente centralização

7 No original: “ (...) recuperación del antiguo absoluto del poder en nombre de la nueva legitimidad de la Nación.” 
do corpo político. A expressão da autonomia terá sua radicalidade com a liberdade de consciência e com o imperativo individualista no seio da sociedade, dentro de um corpo político caudatário do grande problema rousseauniano, de como prover concomitantemente a soberania coletiva e a liberdade individual (GAUCHET, 2007, p. 104).

Com o laicismo, é preciso criar e recriar uma nova moral que assegure a permanência do coletivo. O conflito com o partido da heteronomia demandava novas opções de comunhão cívica. Era preciso dar algo em troca da religião. O papel da escola enquanto instituição passa a ser o de manter essa coesão em torno do princípio coletivo, e para isso abre sua pedagogia com vistas ao futuro. Mas o que acontece quando o seu objeto de confrontação, a religião, não aparece mais como um inimigo envolvente que ditava a razão de ser do laicismo? O grande êxito da democracia se mostrou no desaparecimento do seu rival, e o fim da sua disputa com o partido da heteronomia teve circunstâncias que mudaram tanto o conteúdo da fé quanto o conteúdo da política. Desde o surgimento da sociedade civil e quando a sociedade passou a ser representada em blocos, a intenção era estar no Estado. No que tange à religião, com a lei de $1905^{8}$ as igrejas ganham liberdade de culto, que passa a ser regulado, tornando-se passível de aplicação penal em caso de transgressão. A supremacia do aparato público em relação à religião é destacada nessa lei pelo lugar em que aloca a religião. O direito público passa a assegurar o culto, os símbolos religiosos, os estabelecimentos e os bens pertencentes à Igreja Católica.

Com o laicismo deslocando a religião para a sociedade civil, resta esclarecer o seu desdobramento durante o século XX. O resultado desse impulso democrático que elevou o papel da autonomia política do Estado e estabeleceu o imperativo da liberdade de consciência será visto na emergência de uma sociedade plural e fragmentada, em que os papéis da política e da religião se recompõem sob outro fundamento. 


\section{Política representativa e individualismo religioso}

O esgotamento da força inicial do laicismo devido a sua vitória diante da religião teve consequências para o conteúdo da fé. Delegada para fora do espaço político, a religião encontrou seu lugar no indivíduo e na esfera privada, provocando um ressignificado da sua função e do seu papel.

Típico fenômeno da contemporaneidade, o individualismo religioso é um diagnóstico global. Hervieu-Leger (1999, p. 29) chama de estilhaçamento da religião esse fenômeno de fragmentação das tradições relativas ao sagrado, seu abandono de centralizadora do coletivo. A paisagem do religioso na modernidade é caracterizado pela individualização e subjetivação das crenças e práticas (Ibid., p. 157). A erosão institucional da crença é acompanhada por uma proliferação das bricolagens religiosas, da diversificação das trajetórias de identificação com o sagrado e do desdobramento da peregrinação como experimentação (Ibid., p. 196).

Os séculos XIX e XX são marcados pelo direcionamento inicial da sociedade civil à política, significando, a princípio, um novo devir coletivo. Foi no ímpeto dessa nova possibilidade que as associações e os sindicatos tinham como axiomático a questão da coletividade civil como responsável pelos desdobramentos da sociedade. Havia um afã político que sustentava a necessidade de um pertencimento à res-pública. Entretanto, as consequências de uma época de luta declarada contra a religião teve suas sequelas sentidas para ambos os lados.

A metamorfose que sofre o universo democrático seguirá uma nova lógica de gestão da sociedade. Desfaz-se a hierarquização entre sociedade civil e Estado, e recompõem-se as peças do tabuleiro. O político passa a apresentar uma neutralidade e um esvaziamento do seu sentido. Gauchet chamará a atenção para as consequências do individualismo que emerge na sociedade civil (GAUCHET, 2003, p. 88). Ele recoloca todo o problema entre a religião e a política em outros moldes. A nova disposição da sociedade promove um retorno da religião como reserva de sentido e promove um afastamento do político enquanto esfera instrumental. $O$ valor metafísico que representava a coletividade não tem mais sentido em uma sociedade atomizada. A sociedade civil passa a se encontrar à margem da política e independente do Estado. 
No desdobramento da democracia moderna a situação de pluralidade passa ser condição instituída na sociedade. Pluralismo para Gauchet é a "assimilação por parte do crente da existência legítima de outras crenças em relação à sua"” (Ibid., p. 107), ou seja, é uma condição ao nível do vivido e do experimentado que não funciona necessariamente como regra. Quando essa realidade se concretiza no cotidiano da vida social, resta ao Estado,, representativo e neutro, reconhecê-las como legítimas. Quando a política não pode mais oferecer uma opção face à heteronomia religiosa, a vida privada ergue-se como única reserva de sentido. E como a religião foi descolada ao nível da escolha individual, a esfera privada passa a ser um espaço de legítima manifestação do sagrado.

Gauchet deixa claro que a retomada da religião nesse contexto não deve ser interpretada como um reencantamento da sociedade. "A política volta às religiões e não às Igrejas, mas aos indivíduos ${ }^{10} "$ (Ibid, p. 118). O conteúdo religioso passa pelo crivo individual e a crença têm sua utilidade na oferta de um estilo de vida em detrimento de uma verdade objetiva e englobante. Busca-se nela um sentido que satisfaça as demandas das consciências independentes. A demanda por uma significação sagrada perpassa as cercas institucionais diante de uma reapropriação do conteúdo religioso e de sua sucessiva performance independente. O papel do Estado, nessa ótica, é garantir as convicções privadas e permitir afirmações identitárias que compõem a sociedade civil (Ibid., p. 127).

A religião se vê obrigada a estar no profano da vida comum. Quando o discurso religioso permanece mais incapaz de dar forma ao coletivo, a sua privatização resulta em novas formas de assimilação dos seus conteúdos. Destarte, a apropriação do sagrado define-se nos termos de uma necessidade individual de significação. O seu uso definirá o seu objetivo. Nesse contexto, a política aparece como a representação legítima que permite a manutenção dessas escolhas identitárias. Nas palavras de Gauchet (Ibid., p. 131-132):

Antes, representar queria dizer passa por cima das diferenças entre os seres e os grupos para chegar a manifestar a verdade coletiva na unidade de sua vontade. Agora, se trata de exibir as diferenças,

\footnotetext{
$9 \quad$ No original: “(...) la assimilación por parte del creyente de la existencia legítima de outras creencias en relación con la suya própria."

$10 \quad$ No original: "Esta función de compreensión deserta de la política para volver a las religiones, entre otras, pero no regressa a las Iglesias: passa a los indivíduos."
} 
assegurar-lhes visibilidade no espaço público, torna-las legíveis em todos os momentos do processo político, que não se percam no passo à elaboração da decisão coletiva ${ }^{11}$.

A participação igualitária no debate público passa a levar em conta as diferenças dos outros. Essa situação legítima de pluralidade encontra seu centro na radicalidade representativa da democracia moderna. Essa distância instaurada dentro do movimento da democracia resulta em uma descontinuidade atenuada entre os administrados e o político. Se antes, para participar da esfera pública era preciso despir-se da vida privada, agora é preciso afirmá-la identitariamente dentro de um contexto de pluralidade. O eixo da representatividade coletiva faz-se sentir na expressão das minorias diante de uma sociedade demasiadamente diferenciada.

\section{Considerações finais}

Segundo a percepção de Gauchet, a cisão radical provocada pelo surgimento do Estado define as bases das futuras revoluções políticas ao longo da história. Não se trata de observar a religião somente como privatizada ou expulsa de cena. O processo geral está em perceber como o totalmente Outro foi apropriado pela sociedade e sofreu metamorfoses. A saída da religião se deu por ela mesma, por um movimento interno que não tardou em culminar em outras formas substitutivas do Uno, como a religião civil. Nas sociedades que aboliram a religião do papel de organizar o ser-conjunto e onde se constata não haver mais nada que a unisse a um fundamento religioso, Gauchet mostra que esse processo está ligado, mutatis mutandis, a um problema muito maior que nos remete às sociedades sem escrita e sem Estado. Daí a importância em trazer a obra de Clastres para a discussão, da qual Gauchet tem influência e ao mesmo tempo localiza sua questão inicial.

O desencantamento do mundo para Gauchet é considerado o maior acontecimento da história humana. A saída da religião primeira será um marco definitivo na organização do ser-conjunto, e todas as formas religiosas subsequentes não preencherão mais o abismo formado pelo surgimento do Estado. Por mais

\footnotetext{
$11 \quad$ No original: “Antes, representar quería decir pasar por encima de las diferencias entre los seres y los grupos para llegar a manifestar la verdad colectiva en la unidad de su voluntad. Ahora se trata de exhibir las diferencias, asegurarles visibilidad en el espacio público, hacerlas legibles en todos los momentos del proceso político, que no se pierdan en el paso a la elaboración de la decisión colectiva."
} 
fundamentalista que possa ser a religião, não será capaz de prover um reencantamento como o do reino do passado puro.

O diagnóstico de Gauchet é contundente. As transformações da política e da religião confluíram no arranjo moderno da democracia. Diante de um processo de metamorfose do religioso, o deslocamento do Uno precipitou em um arranjo societário sem precedentes. Em um primeiro momento, aquilo que a religião criou se volta contra ela mesma afirmando sua legitimidade substantiva, para logo adiante ela retornar dentro de outros moldes e receptividades. A contribuição da tese gaucheniana é permitir a visualização da democracia moderna fazendo parte de um evento mais geral da história humana do que se pensava. A relação do político com o religioso, nesse sentido, é o ponto central de onde resultam as transformações mais imprevisíveis possíveis do estarjunto-coletivo.

\section{Referências}

CLASTRES, Pierre. A Sociedade Contra o Estado. Rio de Janeiro: Ed. Francisco Alves, 1982.

EVANS-PRITCHARD, E.E. Os Nuer. São Paulo: Editora Perspectiva, 1993.

GAUCHET, Marcel. El Desencantamiento del Mundo: Una Historia política de la religión Madrid: Editorial Trotta, 2005.

GAUCHET, Marcel. La Condition Politique. Paris: Gallimard, 2005.

GAUCHET, Marcel. La religion en la democracia. Madri: El Cobre, 2003.

GAUCHET, Marcel. La revolución moderne. Paris: Gallimard, 2007.

HABERMAS, Jürgen. Mudança estrutural da esfera pública. Rio de Janeiro: Tempo Brasileiro, 1984.

HERVIEU-LEGER, Danièle. La Religion en Mouvement: Le Pèlerin et le converti. France: Flammarion, 1999.

Recebido: 05/07/2015

Received: 07/05/2015

Aprovado: 15/07/2015

Approved: 07/15/2015 